\title{
The Use of the MIDAS Questionnaire to Assess Migraine and Tension Type Headache in Adolescents
}

\author{
Adolesanlarda Migren ve Gerilim Tipi \\ Baş Ağrılarında MIDAS Ölçeğinin Kullanımı
}

Sait KILIÇ, MD, Msc, ${ }^{a}$

Orhan DERMAN, MD, Prof., ${ }^{a}$ Sinem AKGÜL, MD, Msc, ${ }^{a}$ Nuray KANBUR, MD, Prof., ${ }^{a}$ Tezer KUTLUK, Dr.Prof., Sabiha AYSUN, MD, Prof.a,b

aDepartment of Pediatrics, Division of Adolescent Medicine, ${ }^{b}$ Division of Pediatric Neurology, Hacettepe University, İhsan Doğramacı Children's Hospital, Ankara

Geliş Tarihi/Received: 16.06 .2011 Kabul Tarihi/Accepted: 29.11.2011

This study was presented as a poster presentation at the 15. EPNS 2009 BI-ENNIAL Congress, Harrogate-England 2009.

Yazıșma Adresi/Correspondence: Sinem AKGÜL, MD, Msc Hacettepe University, Department of Pediatrics, Division of Adolescent Medicine, Ankara, TÜRKIYE/TURKEY

sinemhusnu@yahoo.com Ihsan Doğramacı Childrens' Hospital,

\begin{abstract}
Objective: Headache is the most common type of pain that children and adolescents complain as well as being the most common neurological symptom. Among all school-age children, $15-20 \%$ experience headache and $3-5 \%$ of these are migraine. To determine the grade of disability caused by migraine, a specific scale, the Migraine Disability Assessment (MIDAS) questionnaire has been developed. Our objective was to gain information about the evaluation of different types of headaches in adolescents by using the Turkish version of the MIDAS, and to investigate its reliability for differentiation of migraine and tension type headaches. Material and Methods: Eighty two adolescents between the ages of 10 and 16 years were asked questions about the characteristics of their headaches and then the MIDAS questionnaire was administered. The type of headache was then determined according to the International Classification of Headache Disorders Criteria-II (ICHD-II). Results: In 45 patients (54.9\%) tension type, in 20 patients (24.4\%) migraine, in 10 patients $(12.2 \%)$ psychogenic type and in seven (8.5\%) patients a mixed or non-specific headache was found. It was found that patients with tension type headaches were more likely to have a grade 1 score $(48.9 \%)$ whereas migraine type headache was more common in grade $4(45 \%)$. Conclusion: We believe that modification of the MIDAS questionnaire to meet the needs of adolescent patients will help in the differentiation between different types of headaches.
\end{abstract}

Key Words: Migraine disorders; tension-type headache; adolescent

ÖZET Amaç: Baş ağrısı çocuk ve ergenlerde en sık görülen ağrı şikâyeti ve nörolojik semptomdur. Okul çağı çocukların \%15-20'sinde baş ağrısı görülmektedir ve bunların \%3-5'i migrendir. Migrene bağlı gelişen ağrının şiddet derecesini göstermek için MIDAS (Migraine Disability Assessment) ölçeği geliştirilmiştir. Çalışmanın amacı, MIDAS ölçeğinin Türkçe versiyonunun, adolesanlarda farklı baş ağrısı çeşitlerinin değerlendirilmesinde kullanılması, gerilim, migren ve diğer baş ağrısı tiplerinde ağrının şiddet derecesi konusunda bilgi sahibi olmak ve gerilim tipi ile migren tipi baş ağrılarının ayrımında kullanılabilirliğini değerlendirmektir. Gereç ve Yöntemler On-on altı yaşlar arasında 82 hastaya MIDAS ölçeği uygulandı ve baş ağrılarının özellikleri sorgulandı. Baş ağrısı sınıflaması Uluslararası Baş Ağrısı Sınıflama Kriterlerine göre yapıldı. Bulgular: Hastaların 45 $(\% 54,9)$ 'inde gerilim tipi, 20 (\%24,4)'sinde migren tipi, 10 (\%12,2)'unda psikojenik tip ve 7 $(\% 8,5)$ 'sinde miks tipi veya non spesifik baş ağrısı saptandı. Gerilim tipi baş ağrısı olan hastalarda MIDAS skoru sıklıkla evre $1(\% 48,9)$ saptanırken, migren tipi hastalarda evre 4 daha sık olarak saptandı (\%45). Sonuç: MIDAS ölçeğinin adolesan hastaların ihtiyaçlarına göre modifiye edilmesiyle, başağrısının tipinin ayrımında kullanılabileceğini düşünüyoruz.

Anahtar Kelimeler: Migren bozuklukları; gerilim tipi başağrısı; ergen

Turkiye Klinikleri J Med Sci 2012;32(2):466-71

doi:10.5336/medsci.2011-25330

Copyright $@ 2012$ by Türkiye Klinikleri
$\mathrm{H}$ eadache is the most common type of pain that children and adolescents complain as well as being the most common neurological symptom. ${ }^{1}$ Epidemiologic studies have shown that $15-20 \%$ of all 
school-age children experience headache and 3-5\% of these are migraines. ${ }^{2}$

Studies show that the severity of the disease is assessed most efficiently by knowing the grade of the disability of the patient, and that disability scoring is the basis for physicians to define treatment needs and strategies. ${ }^{3}$ To determine the grade of disability caused by migraine, a specific scale, the Migraine Disability Assessment (MIDAS) questionnaire has been developed. This is a self-administered five scored items test and the translation into Turkish has been shown to be reliable and valid. ${ }^{4}$

During childhood and adolescence, most of the chronic headaches are idiopathic in origin and are classified as migraine or tension-type headache. ${ }^{5}$ It is important to differentiate the type of headache and as there are no biological markers, physicians rely on diagnostic criteria. ${ }^{6}$ Currently the International Classification of Headache Disorders $2^{\text {nd }}$ addition is used in the differentiation; the classification separates the primary headache disorders from the secondary headache disorders. The primary headaches include, most importantly, migraine, tension-type headache, and cluster headache. The secondary headaches are attributed to some other causative disorders specified in the diagnostic criteria attached to them. ${ }^{7}$

However, diagnostic problems arise from the overlap of these criteria and the symptoms of migraine and tension type headache. Migraine-like symptoms can often be observed in patients with tension type headache. ${ }^{8}$ MIDAS questionnaire was developed by Stewart et al. and shown to be reliable and valid to determine the grade of disability caused by migraine. ${ }^{9}$ Headache sufferers answer five questions, scoring the number of days in the past three months of activity limitations due to migraine. ${ }^{4,10}$ The questionnaire is based on information in terms of missed days of paid work/school, household work/ chores, and non-work time (family, social, and leisure activities), and the score is derived as days missed due to a headache and when the productivity was reduced by at least half is also reported. ${ }^{11}$ The questionnaire is given in Table 1.

MIDAS questionnaire was translated into Turkish to provide the questionnaire for the benefit of patients with migraine in Turkish daily clinical practice, and Turkish version of the MIDAS has shown to be equivalent to the English version of MIDAS in terms of internal consistency, test-retest reliability, and validity. ${ }^{2}$ The Turkish version of MIDAS showed a highly positive correlation between the physician and the patient, and the applied total MIDAS scores in three visits $(\mathrm{R}=0.87,0.83$, and 0.90 , respectively, $\mathrm{p}<0.001)$. Internal consistency of MIDAS was found to show acceptable $(>0.7)$ or excellent $(>0.8)$ levels in both patient and physician applied MIDAS scores, respectively. Total MIDAS score showed good test-retest reliability $(\mathrm{R}=0.68){ }^{2}$

Our aim was to gain information about the evaluation of different types of headaches in adolescents by using the Turkish version of the MIDAS and to investigate whether it is a reliable tool to be used in the differentiation of migraine and tension type headaches.

\section{MATERIAL AND METHODS}

\section{PARTICIPANTS}

The present study was performed between MarchSeptember 2008 and included 82 adolescents between the ages of 10 and 16 years with a chief complaint of headache who were admitted to

TABLE 1: MIDAS questionnaire.

MIDAS questionnaire

1. On how many days in the last three months did you miss work or school because of your headache?

2. How many days in the last three months was your productivity at work or school reduced by half or more because of your headache?

3. On how many days in the last three months did you not do household work because of your headache?

4. How many days in the last three months was your productivity in household work reduced by half or more because of your headache?

5. On how many days in the last three months did you miss family, social, or leisure activities because of your headache? 
Hacettepe University Ihsan Doğramacı Children's Hospital, Division of Adolescent Medicine. Patients with secondary headaches that were a result of other medical conditions, such as an infection or increased pressure due to an intracranial tumor as well as the patients with mental retardation were excluded from the study.

All cases were first evaluated by the same pediatrician and were asked questions about the characteristics of their headaches such as; how long they have been experiencing headaches, their frequency and severity, the location of the pain, whether it was diffuse or not, what time of the day it occured, the characteristics of the pain (e.g. throbbing, constant pressure, as if the head were being squeezed etc.), volume of the pain, presence of an aura, the factors triggering the pain(chocolate, cheese, ice cream, stress, exercise, menstruation etc.), findings accompanying the pain (pitosis, double vision, visual impairment, diarrhea, vomiting), whether analgesics or sleep relieved the pain, car sickness history, family history of headaches, epilepsy and depression.

Systemic physical examination was performed and then the MIDAS questionnaire was administered. All patients were then referred to the child neurology department where all patients were reevaluated by the same child neurologist and the type of headache was determined according to the International Headache Society (IHS) criteria. ${ }^{8}$

The child neurologist was not aware of the MIDAS score.

The study was approved by the Committee of Research Ethics of Hacettepe University, and written informed consents was obtained from adolescents and their parents contributing to the study.

\section{ANALYSIS OF DATA}

The scores were indicated as the total number of lost days in the last three months, and the MIDAS disability grade was obtained directly from the score as follows; Scores 0-5: Grade 1 (little or no disability), Scores 6-10: Grade 2 (mild disability), Scores 11-20: Grade 3 (moderate disability), Scores 21 and beyond: Grade 4 (severe disability).
The mean and standard deviation, and the median and range (min-max) were presented for data that were normally and not normally distributed, respectively. Each variable were compared with MIDAS grades by using Pearson's Chi-square and Fisher's Exact test.

Statistical significance was set at $\mathrm{p}<0.05$. The data referred to in the methods section was analyzed using SPSS 11.5 (IBM, Chicago).

\section{RESULTS}

Of the 82 patients evaluated, 40 were females (48.8\%) and 42 were males (51.2\%). The mean age of the patients was $12.85 \pm 1.82$ years. In 45 patients (54.9\%) tension type, in 20 patients $(24.4 \%) \mathrm{mi}^{-}$ graine, 10 patients (12.2\%) psychogenic type and in $7(8.5 \%)$ patients a mixed or non-specific headache was found.

Among all patients, $45.1 \%$ had little or no disability (MIDAS grade 1), 31\% had mild to moderate disability (MIDAS grade 2-3) and $23.1 \%$ had severe disability (MIDAS grade 4).

Based on the MIDAS scoring, it was found that patients with tension type headache were more likely to have a grade 1 score $(48.9 \%)$ whereas migraine type headache was more common in grade 4 (45\%) (Figure 1).

When analyzed for gender, 17 (40.5\%) of the male patients were grade 1 , nine $(21.4 \%)$ were grade 2, six (14\%) were grade 3 and 10 (23\%) were grade 4 . In the female patients, $20(50 \%)$ were grade 1 , seven $(17.5 \%)$ were grade 2 , four $(10 \%)$ were grade 3 and nine (22.5\%) were grade 4 .

There was no statistically significant difference between the MIDAS scores of boys and girls $(\mathrm{p}=0.826)$.

The MIDAS disability score significantly increased as the frequency of headaches increased ( $\mathrm{p}=0.029)$.

Seventy-three patients reported bitemporal (89\%), eight patients reported occipital (9.8\%) and one patient reported left-sided headaches. There was no relationship between the location of the headache and the MIDAS disability grade $(\mathrm{p}=0.696)$. 


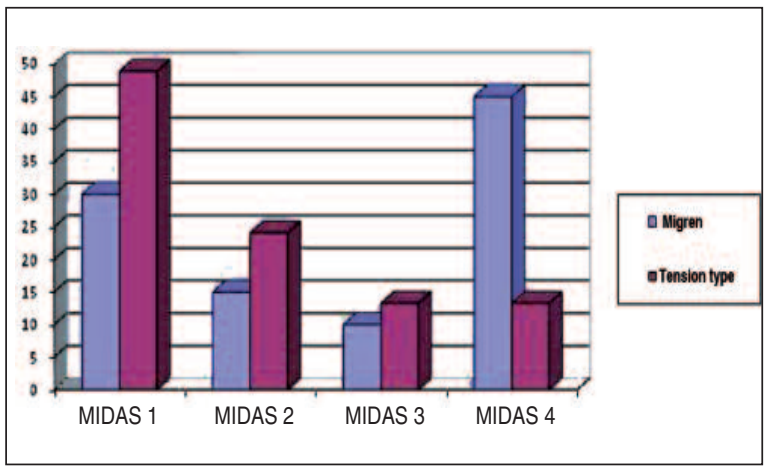

FIGURE 1: Relationship between MIDAS score and the type of headache. (See for colored form http://tipbilimleri.turkiyeklinikleri.com/)

Twenty-two $(26.8 \%)$ patients complained of headaches in the morning, 23 (28\%) in the afternoon and 37 (45.1\%) in the evening. No association was observed between the time of headache occurrence and the MIDAS disability grade $(\mathrm{p}=0.96)$.

Twelve (14.6\%) patients stated they had a throbbing headache, three (3.7\%) stated they felt a constant pressure and $67(81.7 \%)$ stated they felt as if their head was being squeezed. There was no association between the type of pain and the MIDAS disability grade $(\mathrm{p}=0.64)$.

Seventy-three $(89 \%)$ patients did not have an aura whereas nine (11\%) had. A significant increase in the MIDAS disability grades were observed in patients who experienced aura $(\mathrm{p}=0.006)$. Thirty five $(42.7 \%)$ patients indicated presence of a triggering factor whereas $47(57.3 \%)$ did not. There was no association between the presence of a triggering factor and the MIDAS disability grade $(\mathrm{p}=0.53)$.

Seventy-seven (93.9\%) patients stated that analgesics relieved the pain whereas five $(6.1 \%)$ did not.

We found an increase in the MIDAS scores in patients whose pain were unresponsive to analgesics $(p=0.012)$.

Family history revealed 26 (31.7\%) patients had a family history of migraine and one (\%1.2) patient had a family history of epilepsy. We found no association among the family history of headaches, epilepsy and the MIDAS disability grade $(\mathrm{p}=0.59)$.

\section{DISCUSSION}

In current literature, the prevalence of migraine and tension type headache varies considerably.

The results of the current study indicated that tension type headache (54.9\%) was more frequent than migraine (24.4\%) among adolescents with headache. Previous field studies in Turkey have shown the prevalence of tension-type headache to vary between $5-25 \%$ whereas the prevalence was $10.4-58 \%$ for migraine type headache. ${ }^{5,12-14}$

Another study conducted in Turkey evaluated 92 patients of which $41.3 \%$ had migraine type and $18.5 \%$ had tension type headache, and the authors explained the higher prevalence of migraine with the fact that their pediatric neurology unit was a reference center, and the study was not a field study. ${ }^{15}$

The MIDAS questionnaire evaluates headache-related disability based on five disability questions, but it was developed for adults. The score of this questionnaire was highly reliable in population-based samples of migraine headache sufferers in many countries including Turkey. ${ }^{4} \mathrm{De}-$ spite the high prevalence of headache among young people, studies on the validity of evaluation tests have been confined almost entirely to adults and there are only a few studies on the adolescents. ${ }^{16,17}$

For the diagnosis of migraine and tension type headache, ICHD-II proposes separate criteria for diagnosis. ${ }^{8}$ However in daily practice, the presence of various common epidemiological, clinical, and pharmacologic findings make it difficult to differentiate one from another. ${ }^{18}$

The MIDAS questionnaire was originally developed to evaluate migraine, but studies show that it may also be used to evaluate other types of headaches. ${ }^{19}$ The definition and classification of different types of headaches are extremely difficult as they do not have either definitive laboratory tests or objectively defining markers. ${ }^{20}$ Studies show that there is also a significant overlap in the clinic and diagnostic criteria which makes it difficult to differentiate tension type headache from 
other headache disorders and, in particular, migraine. ${ }^{18}$

This study considered the use of the Turkish version of MIDAS questionnaire to distinguish between migraine and tension headache in adolescents with primary headaches in routine clinical practice, and aimed to gain information about the different types of headaches in this age group.

An important result to our study was that based on the MIDAS scoring. It was found that patients with tension type headaches were more likely to have a grade 1 score (48.9\%) whereas migraine type headache was more common in grade 4 (45\%). We believe these results show that the daily life style of patients with migraine type headache are affected more, and that this outcome may help to differentiate between the different types of headaches.

ICHD-2 criteria were formulated for adults, and the only modification for children is shortening the duration criterion for migraine for patients under age 15 years. ${ }^{21}$ The applicability of these criteria in children has been criticized, and the criteria might need further revisions for children and adolescents. ${ }^{22}$

A study by Rossi et al. tested ICHD-II to see whether it could be used to distinguish between migraine and tension headache in children and adolescents. ${ }^{21}$ They found that many children remained unclassifiable and they believe the reason for this was impossibility of giving information about pain quality, pain score, and presence of a pain aggravator. They also found some patients appeared to fulfill the criteria for both probable migraine and tension headache.

Hershey et al. have formed a questionnaire based on MIDAS for pediatric migraineurs, called PedMIDAS. ${ }^{23}$ When used in young migraineurs, PedMIDAS was found to be reliable and sensitive to clinical change. It differs from the original MIDAS in terms of the number and content of the items used to determine the disability score as it also adds questions on doing things at home, play going out and sports. We were not able to use the pedMIDAS for our study since a valid and tested Turkish translation has not yet been developed. Grazzi et al. have aimed to develop a new MIDAS Questionnaire adapted for young patients. ${ }^{16}$ They developed MIDAS junior in which the changes in wording and in content were fairly contained: elimination of the term work from questions 1 and 2, replacement of household work by homework in questions 3 and 4, and replacement of familysocial-leisure activities by doing sport or playing in question. They found a marked improvement particularly for the questions that had been changed and found a significant increase in the correlation coefficients when the original MIDAS and MIDAS junior was compared.

When applying our test, we found that adolescents had problems while answering the third question, which specifically questions house work, and found that most of the patients replied by stating that they did not usually do any house work even when they had no headache.

\section{CONCLUSION}

ICHD-2 criteria are used to identify headaches in both children and adults, however these criteria may be too restrictive to differentiate tension-type headache from migraine. An important result of our study was that, based on the MIDAS scoring, it was found that patients with tension type headache were more likely to have a grade 1 score whereas migraine type headache was more common in grade 4 . Although these finding require confirmation by larger scale studies, this result may help to differentiate between the different types of headaches, and with modification of the MIDAS questionnaire, the reliability and validity may increase in adolescent patients. 
1. Şenbil N, Gürer YKY. [Headache in childhood: general approach]. Turkiye Klinikleri J Pediatr 2004;13(4):254-60.

2. Ertaş M, Siva $A$, Dalkara $T$, Uzuner N, Dora $B$, Inan L, et al.; Turkish MIDAS group. Validity and reliability of the Turkish Migraine Disability Assessment (MIDAS) questionnaire. Headache 2004;44(8):786-93.

3. Deda G, Caksen H, Ocal A. Headache etiology in children: a retrospective study of 125 cases. Pediatr Int 2000;42(6):668-73

4. Gedikoglu U, Coskun O, Inan LE, Ucler S, Tunc T, Emre U. Validity and reliability of Turkish translation of Migraine Disability Assessment (MIDAS) questionnaire in patients with migraine. Cephalalgia 2005;25(6):452-6.

5. Unalp A, Dirik E, Kurul S. Prevalence and characteristics of recurrent headaches in Turkish adolescents. Pediatr Neurol 2006;34(2): 110-5.

6. Ramadan N, Olesen J. Classification of headache disorders. Semin Neurol 2006; 26(2):157-62.

7. Zebenholzer K, Wöber C, Kienbacher C, Wöber-Bingöl $C$. Migrainous disorder and headache of the tension-type not fulfilling the criteria: a follow-up study in children and adolescents. Cephalalgia 2000;20(7):6116.

8. International Headache Society Classification Subcommittee. International classification of headache disorders, $2^{\text {nd }}$ ed. Cephalalgia 2004;24(suppl 1):1-160.

9. Stewart WF, Lipton RB, Whyte J, Dowson A,

\section{REFERENCES}

Kolodner K, Liberman JN, et al. An international study to assess reliability of the Migraine Disability Assessment (MIDAS) score. Neurology 1999;53(5):988-94.

10. Stewart WF, Lipton RB, Kolodner K. Migraine disability assessment (MIDAS) score: relation to headache frequency, pain intensity, and headache symptoms. Headache 2003;43(3): 258-65.

11. Lipton RB, Stewart WF, Sawyer J, Edmeads JG. Clinical utility of an instrument assessing migraine disability: the Migraine Disability Assessment (MIDAS) questionnaire. Headache 2001;41(9):854-61.

12. Hershey $A D$, Winner $P$, Kabbouche MA, Gladstein J, Yonker M, Lewis D, et al. Use of the ICHD-II criteria in the diagnosis of pediatric migraine. Headache 2005;45(10):1288-97.

13. Ozge A, Bŭgdayci R, Saşmaz $T$, Kaleăgasi $H$, Kurt O, Karakelle $A$, et al. The sensitivity and specificity of the case definition criteria in diagnosis of headache: a school-based epidemiological study of 5562 children in Mersin. Cephalalgia 2003;23(2):138-45.

14. Aydın M, Bozdağ Ş, Kabakuş N. [Headaches in childhood]. Turkiye Klinikleri J Med Sci 2010;30(6):1928-36.

15. Aysun $\mathrm{S}$, Yetük M. Clinical experience on headache in children: analysis of 92 cases. $J$ Child Neurol 1998;13(5):202-10.

16. Grazzi L, D'Amico D, Usai S, Solari A, Bussone $\mathrm{G}$. Disability in young patients suffering from primary headaches. Neurol Sci 2004;25 (Suppl 3):S111-2.
17. D'Amico D, Mosconi P, Genco S, Usai S, Prudenzano AM, Grazzi L, et al. The Migraine Disability Assessment (MIDAS) questionnaire: translation and reliability of the Italian version. Cephalalgia 2001;21(10):947-52.

18. Turkdogan D, Cagirici S, Soylemez D, Sur $\mathrm{H}$, Bilge C, Turk U. Characteristic and overlapping features of migraine and tensiontype headache. Headache 2006;46(3): 461-8.

19. Gedikoglu U, Ucler S, Inan LE, Coskun O, Tunc $T$. A preliminary study: validity and reliability of Turkish translation of migraine disability assessment (MIDAS) questionnaire in Turkish patients with chronic tension type headache. Int J Neurosci 2006;116(11):133745.

20. Kaniecki RG. Migraine and tension-type headache: an assessment of challenges in diagnosis. Neurology 2002;58(9 Suppl 6):S15 20.

21. Rossi LN, Cortinovis I, Menegazzo L, Brunelli G, Bossi A, Macchi M. Classification criteria and distinction between migraine and tensiontype headache in children. Dev Med Child Neurol 2001;43(1):45-51.

22. Anttila P. Tension-type headache in childhood and adolescence. Lancet Neurol 2006;5(3): 268-74.

23. Hershey AD, Powers SW, Vockell AL, LeCates S, Kabbouche MA, Maynard MK. PedMIDAS: development of a questionnaire to assess disability of migraines in children. Neurology 2001;57(11):2034-9. 